\title{
An Unforgotten Iron Key
}

\author{
Noor El-Husseini \\ Independent Scholar \\ nelhu052@gmail.com
}

Passports do not recognize the shadows in white tombstones.

What rifle could turn my eyes from you, Palestine?

Your olive gardens have been courted by a bastard son.

Refused, I return to the absent-minded exile.

What rifle could turn my eyes from you, Palestine?

Strange men claimed Sito's home at gunpoint in Ramallah.

Refused, I return to the absent-minded exile.

I am your memory, an unforgotten iron key.

Strange men claimed Sito's home at gunpoint in Ramallah.

She travelled 200 miles south from the 'Height of God.'

I am your memory, an unforgotten iron key,

a worn copy of Wild Thorns by Sahar Khalifeh.

She travelled 200 miles south from the 'Height of God.'

'Your right,' she said, wrapping a kuffiyah over my head.

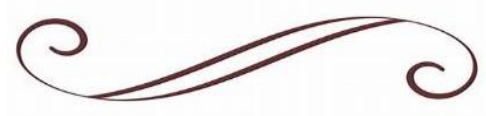

\section{In Loving Memory of Mahmoud Darwish \\ $1941-2008$}

